\title{
The Release of Endogenous Nitrogen and Phosphorus in the Danjiangkou Reservoir: A Double-Membrane Diffusion Model Analysis
}

\author{
Zhiqi Wang, ${ }^{1,2,3}$ Hongxin Ren, ${ }^{2}$ Zhaolong Ma, ${ }^{3,4,5}$ Zhihong Yao, $^{2}$ Pengfei Duan, ${ }^{6}$ \\ and Guodong Ji $\mathbb{D}^{1}$ \\ ${ }^{1}$ Key Laboratory of Water and Sediment Sciences, Ministry of Education, Department of Environmental Engineering, \\ Peking University, Beijing 100871, China \\ ${ }^{2}$ School of Surveying, Mapping, and Geographic Information, North China University of Water Resource and Electric Powder, \\ Zhengzhou 450000, China \\ ${ }^{3}$ River and Lake Protection Center of Ministry of Water Resources, Beijing 100038, China \\ ${ }^{4}$ Department of Hydraulic Engineering, Tsinghua University, Beijing 100084, China \\ ${ }^{5}$ China Institute of Water Resource and Hydropower Research, No. 20 Chegongzhuang West Road, Haidian District, \\ Beijing 100044, China \\ ${ }^{6}$ Key Laboratory of Ecological Security in Water Source Area of the Middle Route of South-to-North Water Transfer Project in \\ Henan Province, Nanyang Normal University, 473000, China
}

Correspondence should be addressed to Guodong Ji; jiguodong@pku.edu.cn

Received 9 November 2020; Revised 12 January 2021; Accepted 25 January 2021; Published 13 February 2021

Academic Editor: Yuan Li

Copyright (c) 2021 Zhiqi Wang et al. This is an open access article distributed under the Creative Commons Attribution License, which permits unrestricted use, distribution, and reproduction in any medium, provided the original work is properly cited.

Endogenous contamination from the newly submerged sediment may have an impact on the water quality of the Danjiangkou Reservoir, the water source of the middle route of the South-to-North Water Diversion Project. In this study, in situ sediment samples were collected at different locations (Guojiashan (DJK1), Kongqueyuan (DJK2), Shijiagou (DJK3), Shiqiao Wharf (DJK4), and Songgang Wharf (DJK5) from the north to the south) of the Danjiangkou Reservoir and the upstream tributary using a columnar sediment sampler and statically cultured in laboratory, and the distribution and release of endogenous $\mathrm{N}$ and $\mathrm{P}$ from the sediment were investigated based on a double-membrane diffusion model. The results showed that the $\mathrm{P}$ contents in the main reservoir and the upstream tributary followed the order of inorganic phosphorus (IP) $>$ organic phosphorus $(\mathrm{OP})>$ calcium - phosphorus $(\mathrm{Ca}-\mathrm{P})>$ iron - phosphorus $(\mathrm{Fe}-\mathrm{P})>$ labile phosphorus $(\mathrm{LP})$. IP accounted for the largest proportion (47.10-59.70\%) of total phosphorus (TP), while LP accounted for only a small proportion (0.10-0.90\%) of TP. There is a significant difference in the spatial distribution of $\mathrm{P}$ at different sampling points, especially for the OP content $\left(226.90 \mathrm{mg} \cdot \mathrm{kg}^{-1}\right)$ with a coefficient of variation of $26.90 \%$. The contents of different forms of $\mathrm{P}$ and $\mathrm{NH}_{4}{ }^{+}-\mathrm{N}$ decreased from the upstream tributary to the main reservoir, which was mainly attributed to the land use type. In the vertical distribution, the contents of different forms of $\mathrm{P}$ in DJK4 and DJK5 decreased with the increase of sediment depth. The contents of $\mathrm{NH}_{4}{ }^{+}-\mathrm{N}^{-}$and $\mathrm{PO}_{4}{ }^{3-}-\mathrm{P}$ in the sediment interstitial water of DJK4 and DJK5 were higher than those in the overlying water. In addition, the contents of $\mathrm{NH}_{4}{ }^{+}-\mathrm{N}$ and $\mathrm{PO}_{4}^{3-}-\mathrm{P}$ were higher in DJK5 than that in DJK4. The static culture experiments showed that $\mathrm{N}$ and $\mathrm{P}$ were mainly released from the sediment-overlying water interface to the overlying water. The release rate of $\mathrm{NH}_{4}^{+}-\mathrm{N}^{-}$and $\mathrm{PO}_{4}^{3-}-\mathrm{P}^{3}$ ranged from $13.08 \mathrm{mg} \cdot\left(\mathrm{m}^{2} \cdot \mathrm{d}\right)^{-1}$ to $21.39 \mathrm{mg} \cdot\left(\mathrm{m}^{2} \cdot \mathrm{d}\right)^{-1}$ and from $3.06 \mathrm{mg} \cdot\left(\mathrm{m}^{2} \cdot \mathrm{d}\right)^{-1}$ to $6.02 \mathrm{mg} \cdot\left(\mathrm{m}^{2} \cdot \mathrm{d}\right)^{-1}$, and the release amount calculated based on the double-membrane diffusion model was $1.17 \times 10^{3} \mathrm{t} \cdot \mathrm{a}^{-1}$ and $0.53 \times 10^{3} \mathrm{t} \cdot \mathrm{a}^{-1}$, respectively. Thus, endogenous contamination from the newly submerged land is an important factor affecting the water quality of the Danjiangkou Reservoir. 


\section{Introduction}

Reservoir sediment is considered to be an important sink of various nutrients in the overlying water [1] and thus even a small change of reservoir sediment can have a substantial impact on the quality of the overlying water [2]. The nutrients accumulated in the sediment such as nitrogen $(\mathrm{N})$ and phosphorus $(\mathrm{P})$ can be released from the sediment back to the overlying water through the interstitial water as a result of convection, diffusion, and resuspension, causing secondary pollution of the overlying water [3]. For instance, the release rate of $\mathrm{NH}_{4}{ }^{+}-\mathrm{N}$ from the sediment is still as high as $3.31 \times 10^{3} \mathrm{t} \cdot \mathrm{a}^{-1}$ in the Dianchi Lake of Yunnan Province, China, after dredging and sewage interception [4], and resuspension of nutrient-rich sediment causes eutrophication for several decades even when external nutrient loads are curtailed [5]. In this case, endogenous release of nutrients from the sediment is the main factor affecting the water quality [6]. Therefore, a better understanding of the distribution of nutrients in the sediment and their release fluxes is essential to take steps to reduce endogenous nutrient load and improve reservoir water quality [7].

The Danjiangkou Reservoir is the main water source of the middle route of the South-to-North Water Transfer Project of China, and thus the water quality has been maintained at a high level for years. However, evidence has emerged that there is an increasing risk of endogenous contamination that can seriously affect the water quality of the reservoir [8]. The overflow weir crest of the Danjiangkou Reservoir was heightened in 2012, resulting in an increase in the storage capacity from 17.45 billion $\mathrm{m}^{3}$ to 29.05 billion $\mathrm{m}^{3}$ [9] and consequently inundation of 17333 ha of farmland [10]. The newly formed sediments contain a higher amount of organic matter compared with the original sediments, which implies a higher risk of endogenous release and contamination. $\mathrm{N}$ is more likely to be released from the newly submerged farmland and orchard of the Danjiangkou Reservoir [11], and P loss is more prominent in the new riparian zone compared with that in the existing riparian zone [12]. Thus, endogenous release of nutrients such as $\mathrm{N}$ and $\mathrm{P}$ from the sediment in the newly submerged area may pose a threat to the water quality of the reservoir. A number of studies have been conducted to investigate the factors affecting the release of nutrients from the sediment, such as existing states and seasonal variations of nutrients, dissolved oxygen, and temperature [13], but little is known about the release of nutrients from the sediment in the newly submerged area.

A number of models have been proposed to describe the release of nutrients from the lake sediment, such as the permeation model, the double-membrane diffusion model, and the surface renewal model. Among them, the doublemembrane diffusion model is particularly suitable to characterize the flux of endogenous nutrients from the kinetic perspective, as it uses mathematical conversion to obtain the double film thickness that is difficult to measure by other models and generalizes the actual complex release process. However, there are three theoretical premises: both water and sediment phases are single homogeneous phases, transmission takes place by means of molecular diffusion, and the total amount of sediment nutrients remains unchanged. It avoids the influence of complicated environmental factors and allows for the estimation of the release of sediment nutrients in a large reservoir area. The $K$ value is calculated from the data obtained from the simulated release experiment, which is the net release coefficient derived from the actual sediment adsorption, precipitation, and microbial action [14].

In this study, in situ sediment samples were collected at different locations of the Danjiangkou Reservoir and statically cultured in laboratory, and the distribution and release of endogenous $\mathrm{N}$ and $\mathrm{P}$ from sediments were investigated based on the double-membrane diffusion model. The results of this study may provide important insights into how to improve the water quality of the reservoir.

\section{Materials and Methods}

2.1. Study Area and Sampling Sites. The Danjiangkou Reservoir is located in the northwest of Hubei province and the southwest of Henan province and consists of Hanjiang and Danjiang reservoirs. The annual average inflow is about 39.48 billion $\mathrm{m}^{3}$ from the Hanjiang River and its tributary Danjiang River, and the terrain is high in the northwest but low in the southeast. The reservoir was put into operation in 1973, and the overflow weir crest was heightened in 2012. Now, it is the largest artificial freshwater lake in Asia, with a water area of about 102275 ha and a storage capacity of about 29.05 billion $\mathrm{m}^{3}$ [15].

In this study, five representative sampling sites were established at Guojiashan (DJK1; $33^{\circ} 02^{\prime} 39^{\prime \prime} \mathrm{N}$ and $111^{\circ} 28^{\prime}$ $46^{\prime \prime} \mathrm{E}$ ), Kongqueyuan (DJK2; $33^{\circ} 0^{\prime} 51^{\prime \prime} \mathrm{N}$ and $111^{\circ} 27^{\prime} 11^{\prime \prime} \mathrm{E}$ ), Shijiagou (DJK3; $32^{\circ} 54^{\prime} 42^{\prime \prime} \mathrm{N}$ and $111^{\circ} 30^{\prime} 47^{\prime \prime} \mathrm{E}$ ), Shiqiao Wharf (DJK4; $32^{\circ} 49^{\prime} 23^{\prime \prime} \mathrm{N}$ and $111^{\circ} 34^{\prime} 28^{\prime \prime} \mathrm{E}$ ), and Songgang Wharf (DJK5; $32^{\circ} 46^{\prime} 02^{\prime \prime} \mathrm{N}$ and $111^{\circ} 38^{\prime} 50^{\prime \prime} \mathrm{E}$ ), as shown in Figure 1 . These sampling sites were about $0.5 \mathrm{~km}$ away from the reservoir shore with a water depth of about $2 \mathrm{~m}$. The overlying water and sediment samples were collected in March and August, 2018. The longitude and latitude of the sampling sites were determined by GPS (see Table 1). AD, DJK 4, and DJK 5 were continuous farmland since 2012 where a large amount $\left(188-356 \mathrm{~kg} \cdot \mathrm{ha}^{-1}\right)$ of chemical fertilizers (mainly potash and phosphate fertilizers) were used with a maximum of $646 \mathrm{~kg} \cdot \mathrm{ha}^{-1}$ [16]. Thus, the doublemembrane diffusion model was used to investigate the effect of the release of endogenous $\mathrm{N}$ and $\mathrm{P}$ on the overlying water at these two sampling sites based on the data collected in March, 2018.

2.2. Sample Collection and Analysis. Columnar sediment samples were collected using a columnar sampler with an organic glass tube $(90 \mathrm{~mm} \times 500 \mathrm{~mm})$, and three parallel samples were collected at each sampling site for static culture experiments. The overlying water samples were also collected at each sampling site without disturbing the sediment. A portion of water samples was encapsulated in $5 \mathrm{~L}$ plastic bottles to supplement the water in static culture experiments, while the rest was encapsulated in $500 \mathrm{ml}$ polyethylene bottles for the measurement of $\mathrm{N}$ and $\mathrm{P}$ concentrations in the overlying 


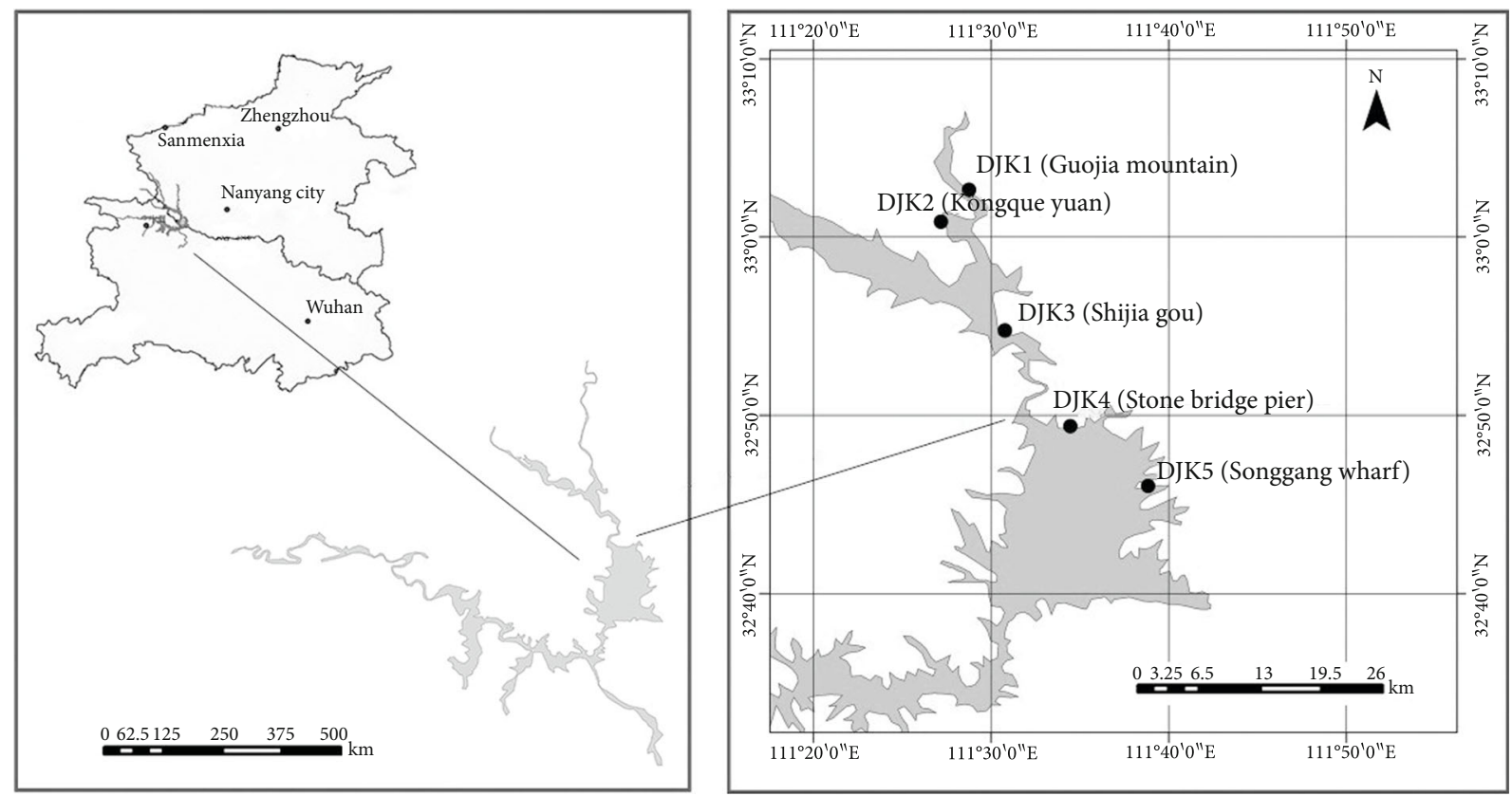

Figure 1: The sampling sites in the Danjiangkou Reservoir.

TABLE 1: $\mathrm{N}$ and $\mathrm{P}$ contents in the overlying water at each sampling site and the original land use type.

\begin{tabular}{|c|c|c|c|c|c|}
\hline Sampling sites & $\begin{array}{r}\mathrm{Bac} \\
\text { concen } \\
\text { overlying } \\
\mathrm{NH}_{4}^{+}-\mathrm{N}\end{array}$ & $\begin{array}{l}\text { nd } \\
\text { in the } \\
\left(\mathrm{mg}^{\left.-\mathrm{L}^{-1}\right)}\right. \\
\mathrm{PO}_{4}{ }^{3-}-\mathrm{P}\end{array}$ & Land use type & Longitude & Latitude \\
\hline DJK1 & 1.08 & 0.12 & Farmland (corn field) & E $111^{\circ} 28^{\prime} 46^{\prime \prime}$ & $\mathrm{N} 33^{\circ} 02^{\prime} 39^{\prime \prime}$ \\
\hline DJK2 & 0.59 & 0.08 & Farmland & $\mathrm{E} 111^{\circ} 27^{\prime} 11^{\prime \prime}$ & $\mathrm{N} 33^{\circ} 00^{\prime} 51^{\prime \prime}$ \\
\hline DJK3 & 0.56 & 0.06 & Moving the topsoil to cultivate fertility & E $111^{\circ} 30^{\prime} 47^{\prime \prime}$ & $\mathrm{N} 32^{\circ} 54^{\prime} 45^{\prime \prime}$ \\
\hline DJK4 & 0.35 & 0.02 & Farmland and woodland & E $111^{\circ} 34^{\prime} 27^{\prime \prime}$ & $\mathrm{N} 32^{\circ} 49^{\prime} 23^{\prime \prime}$ \\
\hline DJK5 & 0.53 & 0.02 & Farmland & E $111^{\circ} 38^{\prime} 50^{\prime \prime}$ & $\mathrm{N} 32^{\circ} 46^{\prime} 02^{\prime \prime}$ \\
\hline
\end{tabular}

water, and several drops of concentrated sulfuric acid were added to reach a $\mathrm{pH}$ value of 2 and shaken uniformly in order to inhibit the microbial activity. Statically cultured samples were cut according to the depth $(0-1 \mathrm{~cm}, 1-2 \mathrm{~cm}, 2-3 \mathrm{~cm}, 3-$ $4 \mathrm{~cm}, 4-5 \mathrm{~cm}, 5-6 \mathrm{~cm}, 6-7 \mathrm{~cm}, 7-8 \mathrm{~cm}, 8-9 \mathrm{~cm}$, and $9-10 \mathrm{~cm}$ ) and centrifuged at $5000 \mathrm{r} / \mathrm{min}$ for $20 \mathrm{~min}$. Sediment interstitial water was obtained and filtered using a $0.45 \mu \mathrm{m}$ fiber filtration membrane for the measurement of $\mathrm{NH}_{4}{ }^{+}-\mathrm{N}$ and $\mathrm{PO}_{4}{ }^{3-}$ - $\mathrm{P}$ concentrations in the sediment interstitial water.

2.3. Static Culture Experiments. The overlying water was removed from columnar sediment samples by siphonage, and then the original overlying water was filtered using the $0.45 \mu \mathrm{m}$ fiber filtration membrane and carefully introduced into the columnar sediment samples along the wall by siphonage. In order to better simulate the field environment of the Danjiangkou Reservoir (the annual average temperature is about $16^{\circ} \mathrm{C}$ ), all columnar sediment samples were placed vertically in a culture vessel with a water depth of $0.40 \mathrm{~m}$ in dark at $16^{\circ} \mathrm{C}$ for 10 days. Water samples were collected at the middle of the sample at the beginning of the experiment and then every $8 \mathrm{~h}$ during the culture. Prior to each sampling, the overlying water was stirred slowly using a slender glass rod in order to ensure uniform sampling and to avoid sediment resuspension. After sampling, an equal amount of original overlying water was supplemented. All samples were kept in a constant temperature incubator at $4^{\circ} \mathrm{C}$.

2.4. Analysis Methods. The contents of $\mathrm{NH}_{4}{ }^{+}-\mathrm{N}$ in the overlying water, sediment, and sediment interstitial water were measured using Nessler's reagent colorimetric method (GB7479-87, National Standards of People's Republic of China), $\mathrm{KCl}$ extraction-distillation method [17], and Nessler's reagent colorimetric method [17], respectively, while those of $\mathrm{PO}_{4}{ }^{3-}-\mathrm{P}$ were measured using molybdenumantimony anticolorimetry (GB11893-89, National Standards of People's Republic of China) and the molybdenum blue coloration method [17], respectively. The states of $\mathrm{P}$ were determined as described in using the Standards, Measurements, and Testing (SMT) method (Standards Measurements and Testing Program of the European Commission) [18] (see Figure 2). Labile phosphorus (LP) was extracted 

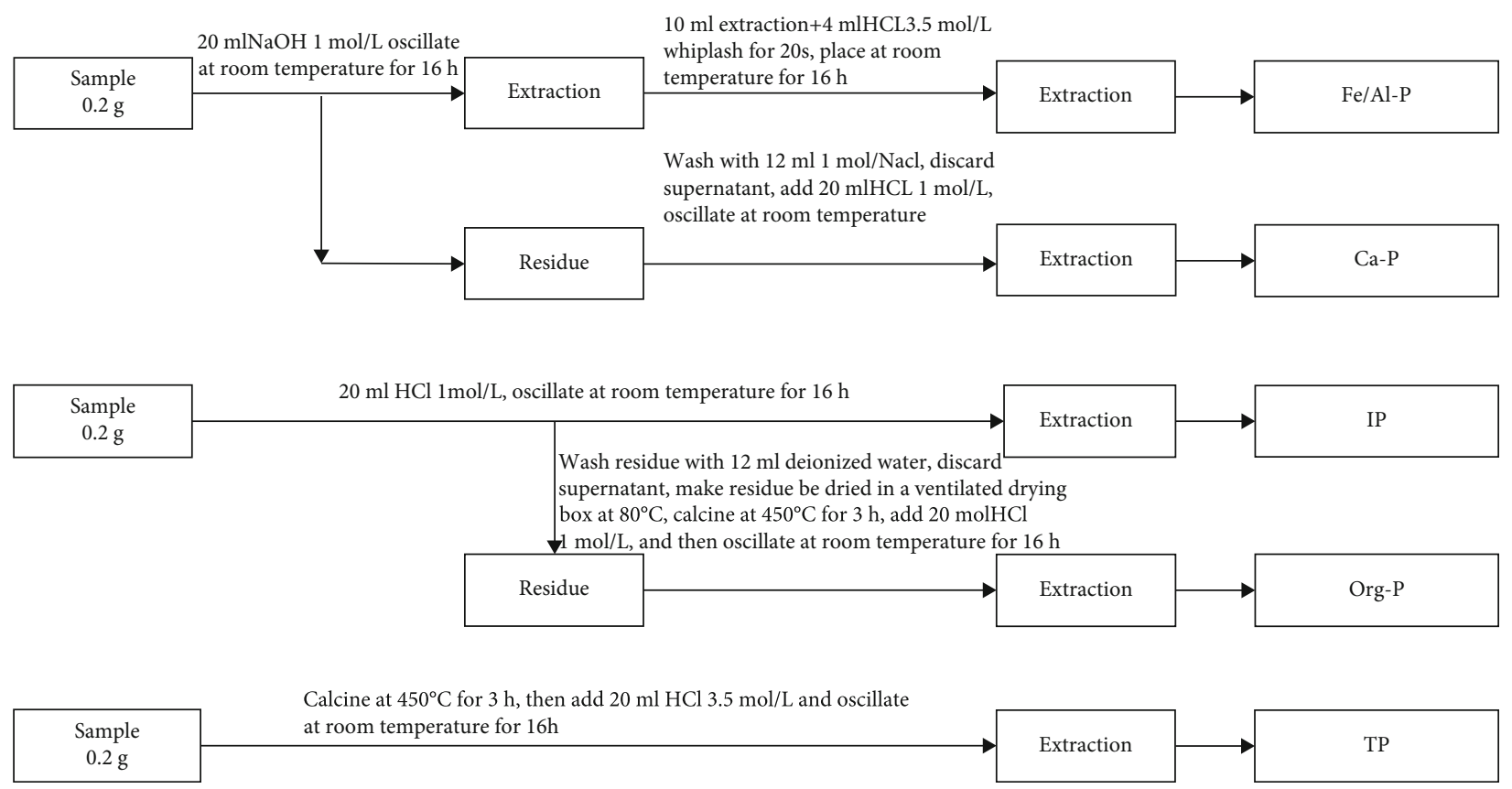

Figure 2: Extraction of P from the sediment by the SMT method.

using $1 \mathrm{~mol} / \mathrm{L} \mathrm{NH}_{4} \mathrm{Cl}$ [19]: $1 \mathrm{~g}$ of sediment was placed in a centrifuge tube, and $25 \mathrm{ml}$ of $\mathrm{NH}_{4} \mathrm{Cl}(1 \mathrm{~mol} / \mathrm{L})$ was added, oscillated for $0.5 \mathrm{~h}$, and centrifuged. The LP content in the supernatant was measured using molybdenum blue colorimetry. All measurements were repeated three times, and the average was reported (the error was within $<5 \%$ ). The significance of spatial difference was analyzed by one-way ANOVA using SPSS 19.0, and figures were plotted using Origin 9.0 and ArcGIS 10.2. Error bars represented the standard deviations $(\mathrm{SD})$ throughout the paper.

\subsection{Calculation of Experimental Results}

2.5.1. Double-Membrane Diffusion Model. A number of models have been proposed to describe the release of contaminants from the lake sediment, such as the permeation model, the double-membrane diffusion model, and the surface renewal model. In this study, the double-membrane diffusion model is used, in which the molecular diffusion coefficient and the ratio of the thickness of double membranes $(K)$ are used instead of the thickness of double membranes that is difficult to determine [20]. Three assumptions are made in this model: (1) both the overlying water and sediment are single homogeneous phases, and the overlying water is well mixed, (2) the mass transfer between the sediment and the overlying water takes place only through molecular diffusion, and (3) the nutrient content is relatively high in the sediment compared with that in the overlying water, and thus nutrient loss due to sediment release is negligible throughout the study. The release processes of nutrients from the sediment into the overlying water consist of (1) migration of nutrients from the interior to the surface of the sediment, (2) interfacial transfer of nutrients to the water side, (3) diffusion through the liquid membrane, and
(4) uniform mixing in the overlying water. Given the above three assumptions, steps 1, 2, and 4 are assumed to occur instantaneously, and thus step 2 is the controlling step of the release processes [21].

According to the double-membrane diffusion model, the transfer flux $N$ should be proportional to the molecular diffusion coefficient $D$ and the concentration gradient in the double membrane, the latter of which is the concentration difference between the two sides of the membrane divided by the thickness of the double membrane $\delta$ :

$$
N=\mathrm{D} \frac{(C w-C)}{\delta},
$$

where $C$ is the contaminant concentration on the water side $\left(\mathrm{mg} \cdot \mathrm{L}^{-1}\right)$, and $\mathrm{Cw}$ is the equilibrium concentration of contaminants in the water phase $\left(\mathrm{mg} \cdot \mathrm{L}^{-1}\right)$.

Let the transfer velocity constant be $\mathrm{K}=\mathrm{D} / \delta$. According to the double-membrane diffusion model and the dynamics theory,

$$
\mathrm{K} V(C w-C)=V \times \frac{d c}{d t}
$$

Thus, the dynamics of contaminant concentration in the water phase can be described as follows:

$$
C=C w\left(1-e^{-\frac{K A}{V} \times t}\right)
$$

where $A$ is the release area $\left(\mathrm{m}^{2}\right)$, and $V$ is the volume of the overlying water $\left(\mathrm{m}^{3}\right)$. 
Eq. (3) can be transformed into

$$
\frac{V}{A} \times \operatorname{Ln}\left(\frac{C w}{C w-C}\right)=\mathrm{K} t
$$

where $V / A$ is the depth of the overlying water in the experimental column [22].

The plot of $(V / A) \times \operatorname{Ln}(C w / C w-C)$ against time $t$ is a straight line through the origin of coordinates, and the slope is the $K$ value [21]. The $K$ values calculated from experimental results are shown in Table 2 .

According to the double-membrane diffusion model, the release flux of contaminants from the sediment is

$$
N=\mathrm{K}(C w-C)
$$

The release rate of contaminants is

$$
\frac{d C}{d t}=\mathrm{K} A(C w-C)
$$

where $A$ is the sediment area $\left(\mathrm{m}^{2}\right)$.

Thus, the annual diffusion amount $W$ is

$$
\mathrm{W}=\mathrm{K}(C w-C) \times V \times t
$$

where $V$ is the volume of the overlying water $\left(\mathrm{m}^{3}\right), V=A H$, $H$ is the depth of the overlying water $(\mathrm{m})$, and $t$ is the diffusion period [21].

2.5.2. Release Rate of Nutrients in Statically Cultured Sediments. The release rate of contaminants can be calculated according to the mass conservation principle:

$$
R=\frac{\left[V\left(\rho_{n}-\rho_{0}\right)+\sum_{j=1}^{n} v_{j-1}\left(\rho_{j-1}-\rho_{\alpha}\right)\right]}{\mathrm{A} t},
$$

where $R$ is the release rate of contaminants from sediment samples, $\mathrm{mg} /\left(\mathrm{m}^{2} \cdot \mathrm{d}\right) ; V$ is the volume of the overlying water (L); $\rho_{0}, \rho_{n}$, and $\rho_{j-1}$ are the contents of contaminants collected at the beginning of the experiment, time $n$ and $j-1$, respectively $(\mathrm{mg} / \mathrm{L}) ; \rho_{\alpha}$ is the contaminant content in the added water $\left(\mathrm{mg} \cdot \mathrm{L}^{-1}\right), v_{j-1}$ is the volume of $j-1$ samples (L); $A$ is the contact area between the sediment and the overlying water $\left(\mathrm{m}^{2}\right)$; and $t$ is the release time $(d)$ [22].

\section{Results and Discussion}

3.1. Distribution of Different Forms of $P$ and $N$ in the Sediment. There is a significant difference in total phosphorus (TP) contents (402.40-560.30 $\mathrm{mg} \cdot \mathrm{kg}^{-1}$ ) among the five sampling sites (DJK 1-5) with a coefficient of variation of $14.4 \%(p<0.01)$, which is consistent with the previous finding in the Danjiangkou Reservoir (530 mg. $\mathrm{kg}^{-1}$ ) [15] but lower than that in the Three Gorges Reservoir $\left(1189 \mathrm{mg} \cdot \mathrm{kg}^{-}\right.$ $\left.{ }^{1}\right)$ [23]. In sampling sites from DJK1 to DJK5, a great amount of $\mathrm{P}$ in chemical fertilizers and crop residues can be fixed in the soil by adsorption, sedimentation, and microbial immo-
TABLE 2: Contaminant migration velocities $(K)$ in the sediment.

\begin{tabular}{lc}
\hline Sampling sites & $K$ values \\
\hline $\mathrm{DJK} 4-\mathrm{NH}_{4}{ }^{+}-\mathrm{N}$ & 0.06 \\
$\mathrm{DJK} 5-\mathrm{NH}_{4}{ }^{+}-\mathrm{N}$ & 0.06 \\
$\mathrm{DJK} 4-\mathrm{PO}_{4}{ }^{3-}-\mathrm{P}$ & 0.15 \\
$\mathrm{DJK} 5-\mathrm{PO}_{4}{ }^{3-}-\mathrm{P}$ & 0.12 \\
\hline
\end{tabular}

bilization [24]. However, the TP contents in DJK 1-5 seem to be less affected by agricultural practices compared with that in the Three Gorges Reservoir. The highest TP content is found in DJK 1, which is 1.34 times that in DJK 4. In general, the TP content decreases from the upstream tributary to the main reservoir, which may be associated with the original land use type [25] and the amount of chemical fertilizers used (see Table 1).

The contents of different forms of $\mathrm{P}$ follow the order of IP $>$ OP $>\mathrm{Ca}-\mathrm{P}>\mathrm{Fe}-\mathrm{P}>\mathrm{LP}$. Thus, IP accounts for the largest proportion (47.10-59.70\%) of TP in the five sampling sites, while the LP content is only $0.98-3.50 \mathrm{mg} \cdot \mathrm{kg}^{-1}$, accounting for a small proportion (0.10-0.90\%) of TP (see Figure 3 ). However, it is noted that LP is a weakly bound phosphate on the sediment surface that is readily exploitable by aquatic organisms, and $\mathrm{P}$ is most easily released from the sediment in the form of LP [26]. The vertical distribution of various forms of $\mathrm{P}$ in DJK 4 shows a decreasing trend with sediment depth and the contents of Fe-P, which can also be easily utilized by aquatic organisms, range from $1.70 \mathrm{mg} \cdot \mathrm{kg}^{-1}$ to $4.70 \mathrm{mg} \cdot \mathrm{kg}^{-1}$, while that in DJK 5 shows a W-shaped decreasing trend and the $\mathrm{Ca}-\mathrm{P}$ contents range from 9.30 to $28.50 \mathrm{mg} \cdot \mathrm{kg}^{-1}$. The vertical distribution of $\mathrm{P}$ may be associated with the environment, sedimentation rate, and age. The greater the sediment depth is, the lower the contents of various forms of $\mathrm{P}$ will be [27]. Fertilizers containing $\mathrm{P}$ were not allowed in early years, thus resulting in less accumulation of nutrients in the sediment; whereas an increasing amount of $\mathrm{P}$ fertilizers are used in recent years, thus resulting in an increase in $\mathrm{P}$ contents in the sediment.

Inorganic $\mathrm{N}$ exists in the sediment and overlying water mainly in the form of $\mathrm{NH}_{4}{ }^{+}-\mathrm{N}$ [28]. Table 3 shows that the $\mathrm{NH}_{4}{ }^{+}-\mathrm{N}$ content ranges from $173.00 \mathrm{mg} \cdot \mathrm{kg}^{-1}$ to $208.10 \mathrm{mg} \cdot \mathrm{kg}^{-1}$ in the five sampling sites, which is slightly higher than that obtained in a previous study $\left(142.30 \mathrm{mg} \cdot \mathrm{kg}^{-1}\right)$ [29]. In line with the study of the Yuqiao Reservoir [30], the $\mathrm{NH}_{4}{ }^{+}-\mathrm{N}$ content also decreases from the upstream tributary to the main reservoir. Compared with the reservoir, the tributary river is characterized by smaller bed slopes and flow velocities, making it easier to accumulate organic matter [31]. The spatial distribution of $\mathrm{P}$ is also affected by agricultural practices at the five sampling sites due to extensive use of chemical fertilizers. In the vertical distribution, the $\mathrm{NH}_{4}{ }^{+}-\mathrm{N}$ content increases as the sediment depth increases (see Figure 3), because $\mathrm{NH}_{4}{ }^{+}-\mathrm{N}$ can be easily diffused from the sediment surface to the overlying water through complex physical, chemical, and biological exchanges [32]. However, the $\mathrm{NH}_{4}{ }^{+}-\mathrm{N}$ content is increased at $4-12 \mathrm{~cm}$. Organic $\mathrm{N}$ is mineralized at an increasing rate in the deep sediment under the effect of ammonifiers, and 

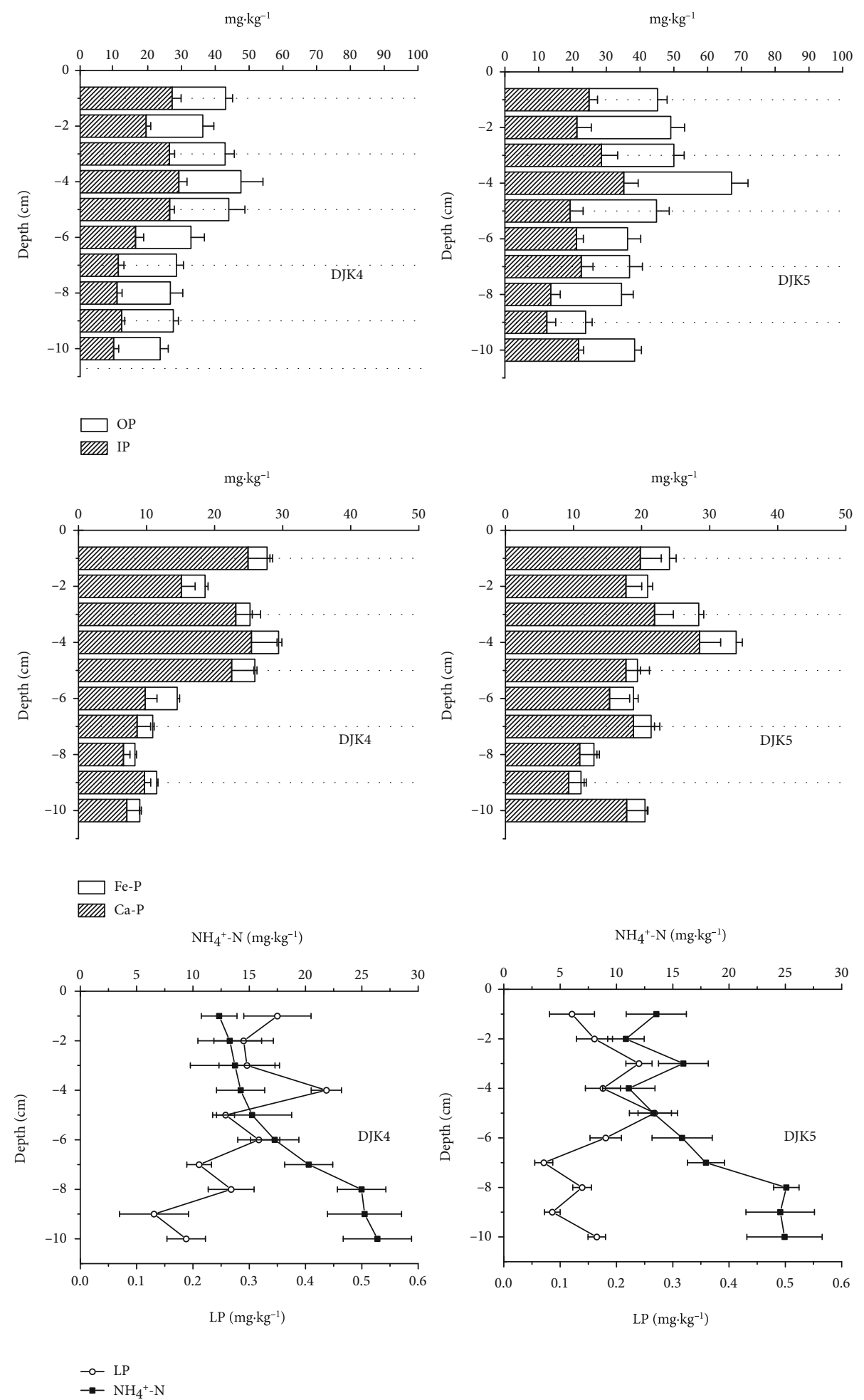

$$
\begin{aligned}
& \rightarrow-\mathrm{LP} \\
& \rightarrow-\mathrm{NH}_{4}{ }^{+} \mathrm{N}
\end{aligned}
$$

Figure 3: Vertical distribution of various forms of $\mathrm{P}$ and $\mathrm{NH}_{4}{ }^{+}-\mathrm{N}$ in the sediments collected from sites DJK4 and DJK5.

more importantly, less oxygen is available as the sediment depth increases, resulting in inhibition of nitrification and thus transformation of less $\mathrm{NH}_{4}^{+}-\mathrm{N}$ into other forms of $\mathrm{N}$. As a consequence, an increase in the $\mathrm{NH}_{4}{ }^{+}-\mathrm{N}$ content is observed at $4-12 \mathrm{~cm} \mathrm{[33].}$

The contents of $\mathrm{NH}_{4}{ }^{+}-\mathrm{N}$ and $\mathrm{PO}_{4}{ }^{3-}-\mathrm{P}$ in the sediment interstitial water of DJK 4 and DJK 5 increase with increasing depth (see Figure 4 ), and they are significantly higher in DJK4 than in DJK5 $(p<0.01)$. The average $\mathrm{NH}_{4}{ }^{+}-\mathrm{N}$ content in the interstitial water at a depth of $10 \mathrm{~cm}$ in samples from DJK4 and DJK5 is $16.00 \mathrm{mg} \cdot \mathrm{L}^{-1}$ and $3.50 \mathrm{mg} \cdot \mathrm{L}^{-1}$ with a coefficient of variation of $42.50 \%$ and $107.70 \%$, respectively. Thus, the $\mathrm{NH}_{4}{ }^{+}-\mathrm{N}$ content varies more dramatically in DJK5 [34]. In DJK5, the $\mathrm{NH}_{4}{ }^{+}-\mathrm{N}$ content increases as the 
TABLe 3: Average contents of $\mathrm{P}$ in the surface sediments of different sampling sites.

\begin{tabular}{lccccccc}
\hline Sampling sites & $\mathrm{LP} /\left(\mathrm{mg} \cdot \mathrm{kg}^{-1}\right)$ & $\mathrm{Fe}-\mathrm{P} /\left(\mathrm{mg} \cdot \mathrm{kg}^{-1}\right)$ & $\mathrm{Ca}-\mathrm{P} /\left(\mathrm{mg} \cdot \mathrm{kg}^{-1}\right)$ & $\mathrm{OP} /\left(\mathrm{mg} \cdot \mathrm{kg}^{-1}\right)$ & $\mathrm{IP} /\left(\mathrm{mg} \cdot \mathrm{kg}^{-1}\right)$ & $\mathrm{TP} /\left(\mathrm{mg}^{\mathrm{kg}}{ }^{-1}\right)$ & $\mathrm{NH}{ }_{4}^{+}-\mathrm{N} /\left(\mathrm{mg} \cdot \mathrm{kg}^{-1}\right)$ \\
\hline DJK1 & $3.50 \pm 0.51 \mathrm{a}$ & $59.40 \pm 5.33 \mathrm{a}$ & $265.50 \pm 25.83 \mathrm{a}$ & $226.90 \pm 18.56 \mathrm{a}$ & $334.60 \pm 20.28 \mathrm{a}$ & $560.30 \pm 28.55 \mathrm{a}$ & $208.10 \pm 27.40 \mathrm{a}$ \\
DJK2 & $0.98 \pm 0.14 \mathrm{~b}$ & $57.01 \pm 4.37 \mathrm{~b}$ & $194.60 \pm 14.00 \mathrm{~b}$ & $230.90 \pm 21.06 \mathrm{a}$ & $279.70 \pm 18.13 \mathrm{~b}$ & $516.50 \pm 24.71 \mathrm{~b}$ & $198.30 \pm 24.50 \mathrm{a}$ \\
DJK3 & $2.94 \pm 0.35 \mathrm{ab}$ & $48.72 \pm 3.47 \mathrm{bc}$ & $180.30 \pm 10.58 \mathrm{~b}$ & $165.20 \pm 11.91 \mathrm{~b}$ & $245.50 \pm 17.14 \mathrm{~b}$ & $452.90 \pm 21.72 \mathrm{~b}$ & $186.40 \pm 26.50 \mathrm{~b}$ \\
DJK4 & $2.75 \pm 0.42 \mathrm{~b}$ & $28.85 \pm 4.67 \mathrm{c}$ & $152.90 \pm 9.42 \mathrm{c}$ & $163.60 \pm 14.58 \mathrm{c}$ & $189.40 \pm 11.45 \mathrm{c}$ & $402.40 \pm 16.72 \mathrm{c}$ & $182.90 \pm 23.80 \mathrm{c}$ \\
DJK5 & $1.61 \pm 0.12 \mathrm{~b}$ & $33.99 \pm 3.42 \mathrm{bc}$ & $177.80 \pm 7.96 \mathrm{c}$ & $205.40 \pm 11.23 \mathrm{~b}$ & $220.50 \pm 9.33 \mathrm{c}$ & $439.00 \pm 16.73 \mathrm{~b}$ & $173.00 \pm 22.90 \mathrm{c}$ \\
\hline
\end{tabular}

Note: different letters after the values indicate significant differences $(p<0.01)$, means \pm standard deviations.
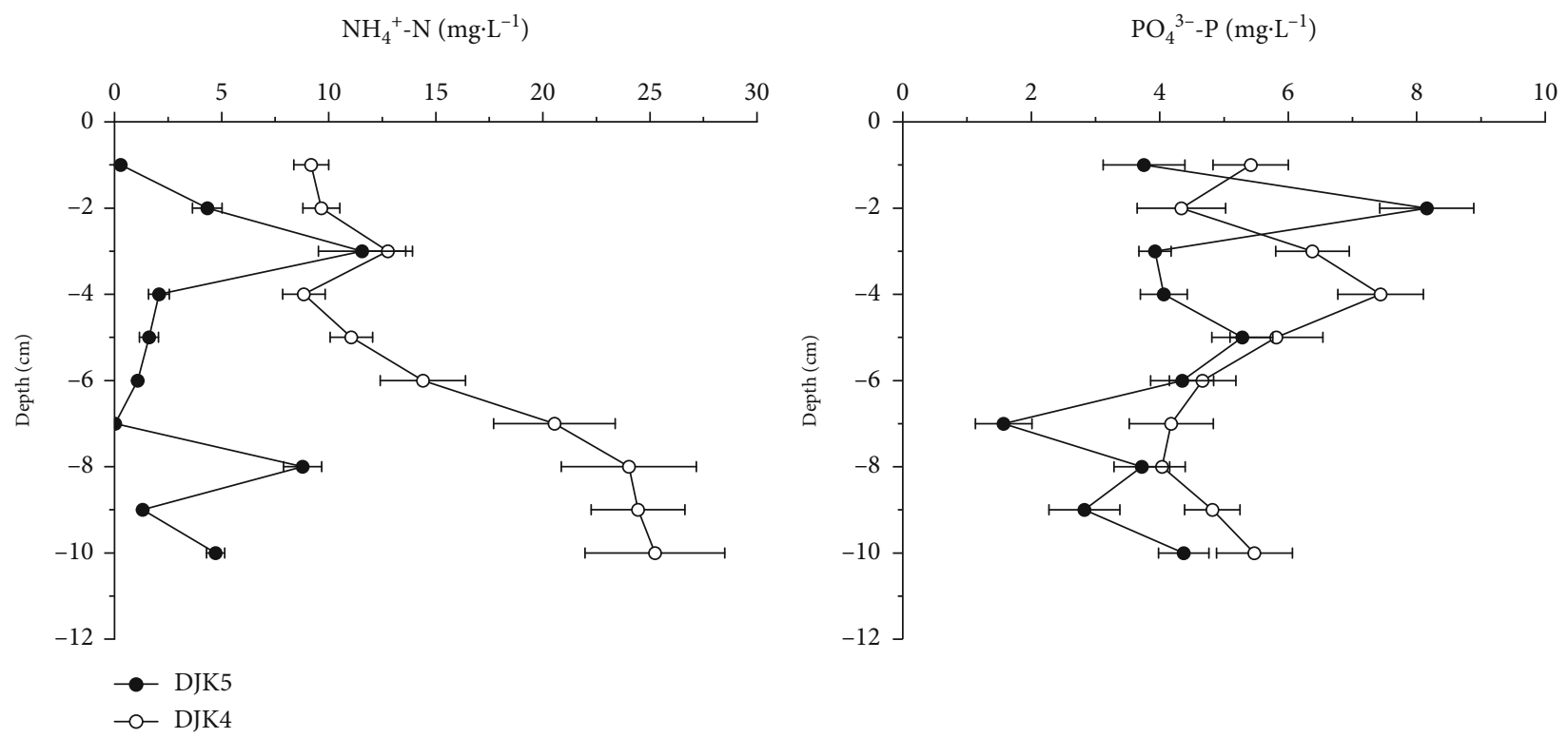

FIgURE 4: Variation of $\mathrm{NH}_{4}{ }^{+}-\mathrm{N}$ and $\mathrm{PO}_{4}{ }^{3-}-\mathrm{P}$ contents in the sediment interstitial water.

depth increases until a maximum of $12.75 \mathrm{mg} \cdot \mathrm{L}^{-1}$ is reached at $3 \mathrm{~cm}$, after which it decreases with further increase of the depth. This agrees well with the study of Liu et al. about the Beili Lake of the Hangzhou West Lake [35] and the study of Wang et al. about the Nansi Lake [36]. The significant difference in the $\mathrm{NH}_{4}{ }^{+}-\mathrm{N}$ content at $4-10 \mathrm{~cm}$ between DJK 4 and DJK 5 can be attributed to the presence of more iron and manganese oxides in DJK5, which act as electron acceptors of $\mathrm{NH}_{4}{ }^{+}$for conversion of $\mathrm{NH}_{4}{ }^{+}$into $\mathrm{NH}_{3}$ gas under anaerobic conditions [37]. It is also noted that the higher $\mathrm{NH}_{4}{ }^{+}-\mathrm{N}$ content in the interstitial water of DJK 4 is consistent with the $\mathrm{NH}_{4}{ }^{+}-\mathrm{N}$ content in the sediment.

The average $\mathrm{PO}_{4}{ }^{3-}-\mathrm{P}$ content in the interstitial water at a depth of $10 \mathrm{~cm}$ in samples from DJK4 and DJK5 is $5.26 \mathrm{mg} \cdot \mathrm{L}^{-}$ 1 and $4.30 \mathrm{mg} \cdot \mathrm{L}^{-1}$ with a coefficient of variation of $20.50 \%$ and $36.20 \%$, respectively, which is related to the high $\mathrm{P}$ content in DJK 4. In DJK 5, the $\mathrm{PO}_{4}{ }^{3-}$-P content first increases and then decreases with increasing depth, and the maximum of $8.16 \mathrm{mg} \cdot \mathrm{L}^{-1}$ is reached at $2 \mathrm{~cm}$; while in $\mathrm{DJK} 4$, the $\mathrm{PO}_{4}{ }^{3-}-\mathrm{P}$ content is maximized at $4 \mathrm{~cm}\left(7.45 \mathrm{mg} \cdot \mathrm{L}^{-1}\right)$ and $10 \mathrm{~cm}$ $\left(5.47 \mathrm{mg} \cdot \mathrm{L}^{-1}\right)$. This is because the $\mathrm{PO}_{4}{ }^{3-}-\mathrm{P}$ in the surface interstitial water can be easily diffused into the overlying water, resulting in a lower $\mathrm{PO}_{4}{ }^{3-}-\mathrm{P}$ content compared with that in the deep interstitial water [38]. In both DJK 4 and
DJK 5, the $\mathrm{PO}_{4}{ }^{3-}$-P content is decreased at $4-7 \mathrm{~cm}$, at which there is a transition from aerobic to anaerobic conditions that can inhibit the effect of aerobic microbes on the active organic detritus and increase the dissolution of iron and manganese oxides under anaerobic conditions, and consequently result in the release of adsorbed $\mathrm{P}$.

3.2. Release of $\mathrm{NH}_{4}{ }^{+}-\mathrm{N}$ from Statically Cultured Sediments. $\mathrm{NH}_{4}{ }^{+}-\mathrm{N}$ is released from the sediment-overlying water interface into the overlying water in March in DJK1-5 (see Figure 5), which is in good agreement with that of the Danjiangkou Reservoir in August [11]. The release rate ranges from $13.08 \mathrm{mg} \cdot\left(\mathrm{m}^{2} \cdot \mathrm{d}\right)^{-1}$ to $21.39 \mathrm{mg} \cdot\left(\mathrm{m}^{2} \cdot \mathrm{d}\right)^{-1}$, and the maximum is observed in DJK3 $\left(21.39 \mathrm{mg} \cdot\left(\mathrm{m}^{2} \cdot \mathrm{d}\right)^{-1}\right)$, which is 1.32 times of the average. It is higher than that in the Meiliang Bay of the Tai Lake at $15^{\circ} \mathrm{C}\left(12.60 \mathrm{mg} \cdot\left(\mathrm{m}^{2} \cdot \mathrm{d}\right)^{-1}\right)$ [39], but lower than that in the Fubao Bay of the Dianci Lake at 14$16^{\circ} \mathrm{C}\left(93.03 \mathrm{mg} \cdot\left(\mathrm{m}^{2} \cdot \mathrm{d}\right)^{-1}\right)$ [40], because organic matter is released in a larger amount from the sediment to the overlying water in DJK3. In the spatial distribution, the coefficient of variation of the $\mathrm{NH}_{4}{ }^{+}-\mathrm{N}$ content is $50.60 \%$ in DJK 4 and $74.30 \%$ in DJK 5, both of which are higher than that in DJK1-DJK3 (18.70\%, 20.90\%, and 20.10\%, respectively) which were predominantly used for agricultural purposes. 

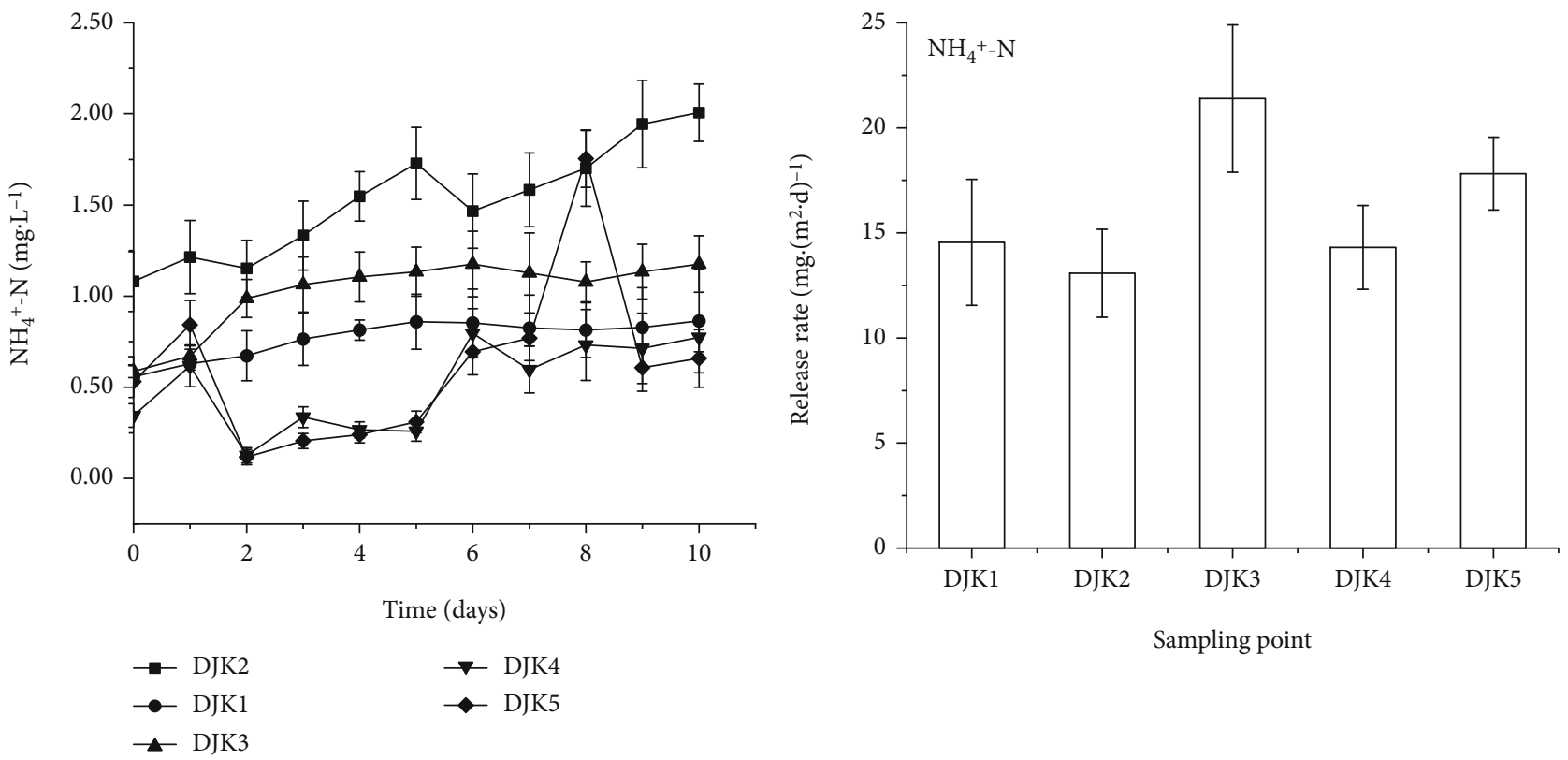

FIgURE 5: The content and release rate of $\mathrm{NH}_{4}{ }^{+}-\mathrm{N}$ in the overlying water.

The flow velocity is generally low at the bottom of the reservoir, making it difficult for nutrients to migrate to the overlying water through the sediment-interstitial water-overlying water interface. Under oxygen-rich conditions, the organic $\mathrm{N}$ in the sediment can be converted into inorganic ions such as $\mathrm{NH}_{4}^{+}$and $\mathrm{NO}_{3}{ }^{-}$by nitrification, which in turn can be diffused to the interstitial water and then to the overlying water and, as a result, have an effect on the $\mathrm{NH}_{4}{ }^{+}-\mathrm{N}$ content in the overlying water [37]. It is also noted that more $\mathrm{NH}_{4}{ }^{+}$would be released under anaerobic conditions compared with that under aerobic conditions [41]. In addition, the decomposition of organic $\mathrm{N}$ results in the formation of $\mathrm{NH}_{3}$ under hypoxia conditions but $\mathrm{NH}_{4}{ }^{+}-\mathrm{N}$ under acidic conditions. The $\mathrm{NH}_{4}{ }^{+}$in the overlying water can also be diffused back to the sediment. The activities of microorganisms in the sediment and subsequent ammonification are reduced in an anoxic environment, and the reducing environment can also promote the denitrification, and finally, $\mathrm{N}$ is released into the atmosphere.

3.3. Release of $\mathrm{PO}_{4}^{3-}-\mathrm{P}$ from Statically Cultured Sediments. The $\mathrm{PO}_{4}^{3-}-\mathrm{P}$ concentration in the overlying water of five sampling points (DJK1-5) tends to increase over time in March, and the coefficient of variation in the reservoir (35.40\% and 64.70\% in DJK 4 and DJK 5, respectively) is significantly higher than that in the upstream tributary $(21.40 \%$, $15.80 \%$, and $26.70 \%$ in DJK1-DJK3, respectively) (see Figure 6). The same phenomenon is also observed for the $\mathrm{NH}_{4}{ }^{+} \mathrm{N}$ content in the overlying water. The release rate of $\mathrm{PO}_{4}^{3-}-\mathrm{P}$ ranges from $3.06 \mathrm{mg} \cdot\left(\mathrm{m}^{2} \cdot \mathrm{d}\right)^{-1}$ to $6.02 \mathrm{mg} \cdot\left(\mathrm{m}^{2} \cdot \mathrm{d}\right)^{-1}$ with an average of $4.65 \mathrm{mg} \cdot\left(\mathrm{m}^{2} \cdot \mathrm{d}\right)^{-1}$, which is lower than that in the Meiliang Bay of the Tai Lake in July $\left(76.55 \mathrm{mg} \cdot\left(\mathrm{m}^{2} \cdot \mathrm{d}\right)\right.$ $\left.{ }^{1}\right)$ [42], but slightly higher than that in the Wuli Lake of the Tai Lake $\left(2.05 \mathrm{mg} \cdot\left(\mathrm{m}^{2} \cdot \mathrm{d}\right)^{-1}\right)$ [43]. The highest release rate is found in DJK1, which is 1.29 times the average. The release rate of $\mathrm{PO}_{4}{ }^{3-}-\mathrm{P}$ decreases from the upstream tributary to the main reservoir, which is consistent with the contamination extent of the sediment. However, the release potential of $\mathrm{P}$ from the sediment is not entirely determined by the $\mathrm{TP}$ amount in the sediment. The release rate of $\mathrm{P}$ is high in water with severe organic contamination, which is related to the presence of a large amount of easily degradable matter [44]. At the beginning of the experiment when there is rich oxygen, the active organic debris in the sediment can release a large amount of $\mathrm{PO}_{4}^{3-}$ under the effect of microorganisms. $\mathrm{PO}_{4}^{3-}$ can be diffused to the interstitial water and then to the overlying water driven by the concentration gradient, forming the first release peak of $\mathrm{PO}_{4}{ }^{3-}$. On the other hand, an anaerobic environment would be formed under the effect of aerobic microbes, and iron and manganese oxides can be easily reduced to increase the solubility, resulting in the release of adsorbed $\mathrm{P}$ and thus the formation of the second release peak of $\mathrm{PO}_{4}{ }^{3-}$.

3.4. Annual Release Amount of $N$ and $P$ from the Sediment and Risk Evaluation. The increase of dam height in 2012 results in a total reservoir area of $1023 \mathrm{~km}^{2}$, a storage capacity of 29.05 billion $\mathrm{m}^{3}$ and an average water depth of about $30 \mathrm{~m}$. After interception of contaminants, the annual release amount of $\mathrm{PO}_{4}{ }^{3-}-\mathrm{P}$ and $\mathrm{NH}_{4}{ }^{+}-\mathrm{N}$ from the newly submerged sediment into the overlying water is calculated to be $0.53 \times 10^{3} \mathrm{t}$ and $1.17 \times 10^{3} \mathrm{t}$, respectively, using formula (7) based on the migration coefficient $(K)$ obtained in experiments and the double-membrane diffusion model at an average temperature of $16^{\circ} \mathrm{C}$ for the Danjiangkou Reservoir. This differs substantially from the release amount of TP based on the SWAT model $\left(1.86 \times 10^{4} \mathrm{t}\right)$ [45], probably because some management practices such as moving the topsoil to cultivate fertility can reduce the endogenous contaminants in the sediment and consequently the release amount of TP. The 

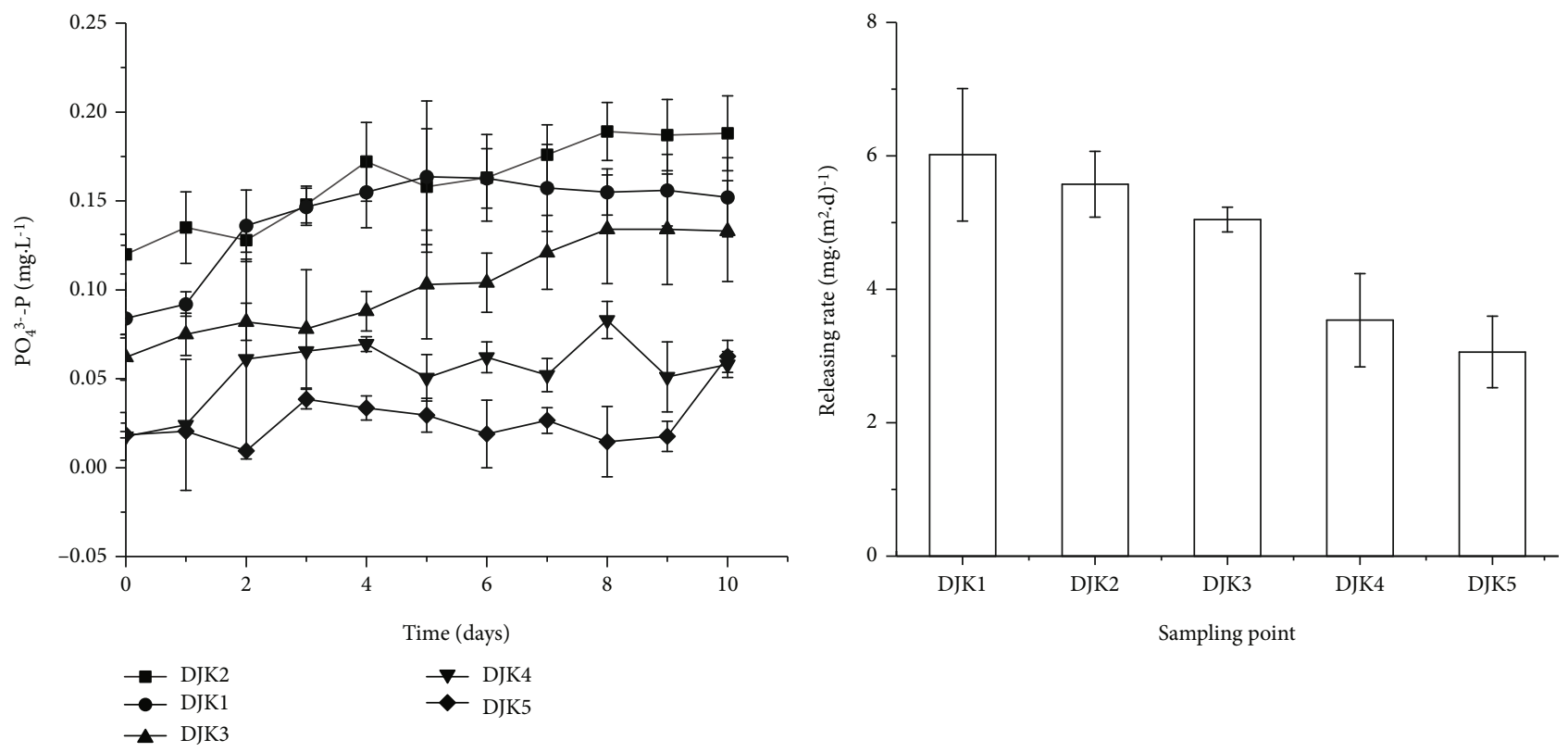

Figure 6: The content and release rate of $\mathrm{PO}_{4}{ }^{3-}-\mathrm{P}$ in the overlying water.

amounts of $\mathrm{NH}_{4}{ }^{+}-\mathrm{N}$ and $\mathrm{PO}_{4}{ }^{3-}-\mathrm{P}$ would be increased from $0.44 \mathrm{mg} \cdot \mathrm{L}^{-1}$ and $0.02 \mathrm{mg} \cdot \mathrm{L}^{-1}$ to $0.57 \mathrm{mg} \cdot \mathrm{L}^{-1}$ and $0.02 \mathrm{mg} \cdot \mathrm{L}^{-1}$ according to the average annual inflow (39.48 billion $\mathrm{m}^{3}$ ) and to $0.62 \mathrm{mg} \cdot \mathrm{L}^{-1}$ and $0.03 \mathrm{mg} \cdot \mathrm{L}^{-1}$ according to the total reservoir storage $\left(29.05\right.$ billion $\mathrm{m}^{3}$ ), respectively. In theory, the water quality is between mesotrophy and eutrophication (0.03-0.05 mg. $\mathrm{L}^{-1}$ for TP and 0.31-0.65 mg. $\mathrm{L}^{-1}$ for TN) [46]. The reservoir storage is increased in the wet season from May to October, and the increase of temperature leads to an increase in dissolved carbon and microbial activities in the soil. As a result, a large amount of $\mathrm{N}$ and $\mathrm{P}$ accumulated in the soil would migrate to the overlying water, which is now the main factor affecting the water quality of the Danjiangkou Reservoir. In addition, the newly submerged area is often in alternative submergence-dry states, and land is cultivated for agricultural production under dry conditions [16], thus resulting in an increase in the diffusion of $\mathrm{P}$ and $\mathrm{N}$ from the sediment into the overlying water.

\section{Conclusions}

(1) The TP contents in the $0-10 \mathrm{~cm}$ sediment samples collected in the Danjiangkou Reservoir and its upstream tributary range from $402.40 \mathrm{mg} \cdot \mathrm{kg}^{-1}$ to $560.30 \mathrm{mg} \cdot \mathrm{kg}^{-1}$, and the contents of different forms of $\mathrm{P}$ follow the order of IP $>\mathrm{OP}>\mathrm{Ca}-\mathrm{P}>\mathrm{Fe}-\mathrm{P}>$ LP. The spatial difference in $\mathrm{P}$ contents among the five sampling points may be related to the original land use type

(2) The average $\mathrm{PO}_{4}{ }^{3-}-\mathrm{P}$ and $\mathrm{NH}_{4}{ }^{+}-\mathrm{N}$ contents in the interstitial water of DJK 4 and DJK 5 are higher than those in the overlying water, and thus $\mathrm{PO}_{4}{ }^{3-}-\mathrm{P}$ and $\mathrm{NH}_{4}{ }^{+}-\mathrm{N}$ are likely to be released from the sediment to the overlying water
(3) Both experimental and calculation results show that $\mathrm{N}$ and $\mathrm{P}$ are easily released from the sediment to the overlying water, and thus endogenous contamination from the newly submerged sediment is an important factor affecting the water quality of the Danjiangkou Reservoir

\section{Data Availability}

The data used to support the findings of this study are available from the corresponding author upon request.

\section{Conflicts of Interest}

The authors declare no conflict of interest.

\section{Acknowledgments}

This study was supported jointly by the National Key Research and Development Project of China (No. 2019YFC0409202), the Foundation for Innovative Research Groups of the National Natural Science Foundation of China (No. 51721006), High Level Talent Support Program of North China University of Water Resources and Electric Power, and Special Support for Innovative Scientific and Technological Team of Water Ecological Security in the water source area of the middle route of South-to-North Water Diversion in Henan Province.

\section{References}

[1] C. X. Fan, L. Zhang, J. J. Wang, C. H. Zheng, G. Gao G, and S. M. Wang, "Process and mechanism of the effects of lake sediment dredging on endogenous release," Science Bulletin, vol. 3, no. 15, pp. 1523-1528, 2004. 
[2] X. Li, L. X. Song, D. B. Ji et al., "Characteristics of nitrogen release at the sediment-water interface in the typical tributaries of the three gorges reservoir during the sensitive period in spring," Environmental Science, vol. 39, no. 3, pp. 1113-1121, 2018.

[3] W. Qu, L. L. Gong, Z. Y. Deng et al., "Estimation of nitrogen diffusion flux at the interface between sediment and overlying water before and after desilting in the South Han dyke channel in 2017," Wetland Science, vol. 18, no. 4, pp. 468-474, 2020.

[4] W. Wang, H. Yan, L. X. Jiao et al., "Characteristics and influencing factors of nitrogen endogenous load in sediments of Dianchi Lake," China Environmental Science, vol. 35, no. 1, pp. 218-226, 2015.

[5] K. R. Reddy, M. M. Fisher, and D. Ivanoff, "Resuspension and diffusive flux of nitrogen and phosphorus in a hypereutrophic lake," Journal of Environmental Quality, vol. 25, no. 2, pp. 363371, 1996.

[6] Z. H. Zhibo, L. I. Tao, C. A. Qimeng, Z. H. Ju, and D. E. Huanguang, "Spatial distribution and stoichiometric characteristics of carbon, nitrogen and phosphorus in sediment Potamogeton crispus system of Dongping Lake," Environmental Chemistry, vol. 39, no. 8, pp. 2263-2271, 2020.

[7] H. Cui, S. Chen, C. Yang, W. Y. Tang, P. Ying, and H. B. Yi, "Characteristics of endogenous pollution and release of sediments from Hengshan reservoir in Yixing City," Environmental Science, vol. 425, no. 3, pp. 1-14, 2020.

[8] S. B. Liu, N. X. Chen, S. L. Hao, L. Yang, and Q. G. Chang, "Evaluation of ecological service value of soil and water conservation in Danjiangkou Reservoir area and its upper reaches," Yellow River, vol. 40, no. 2, pp. 88-92, 2018.

[9] H. Liu, J. Wu, J. Yin, M. Wang, and X. L. Chen, "Estimation and change of dynamic storage capacity of Danjiangkou Reservoir," Chinese Journal of Applied Ecology, vol. 29, no. 8, pp. 2658-2666, 2018.

[10] J. Z. Li, X. Jiang, S. H. Wang, W. W. Wang, and J. Y. Chen, "Characteristics and distribution of heavy metals in sediments of Danjiangkou reservoir," China Environmental Science, vol. 36, no. 4, pp. 1207-1217, 2016.

[11] Z. X. Zeng, P. Lei, H. Zhang, B. Q. Shan, and Y. H. Ye, "Nitrogen and phosphorus fractions and releasing characteristics of the soils from the representative water-level-fluctuating zone of Danjiangkou reservoir," Journal of Environmental Science, vol. 35, no. 5, pp. 1383-1392, 2015.

[12] W. Yin, W. Zhu, J. S. Lei, H .Y. Jia, and Z. X. Zeng, "Soil nutrient distribution of different land use types in typical watershed of Danjiangkou reservoir," Journal of Yangtze River Basin Resources and Environment, vol. 24, no. 7, pp. 1185-1191, 2015.

[13] Y. Wang, W. Xu, and W. Hu, "Distribution and pollution assessment of nitrogen and phosphorus in sediments of Chaohu Lake," Environmental Science, vol. 621, no. 6, pp. 117, 2020 .

[14] J. F. Wang, J. G. Chen, W. Luo, H. Zhang, and P. P. Yu, "Comparative study on estimation methods of endogenous phosphorus release flux in sediments of Hongfeng Lake," Earth and Environment Earth Environment, vol. 46, no. 1, pp. 1-6, 2018.

[15] B. Li, Y. Wang, Y. Zheng et al., "Temporal and spatial variation of nutrients and heavy metals in surface sediments before and after water transfer in Danjiangkou Reservoir," Environmental Science, vol. 39, no. 8, pp. 3591-3600, 2018.
[16] L. Q. Zhang, M. Wu, and Y. S. Wan, "Study on countermeasures for water quality security of the Danjiangkou Reservoir," Chinese Water Conservancy, vol. 36, no. 1, pp. 44-47, 2018.

[17] S. D. Bao, Soil Agrochemical Analysis, China Agricultural Press, Beijing, China, 3rd edition, 1999.

[18] V. Ruban and P. Pardo, "Harmonized protocol and certified reference material for the determination of extractable contents of phosphorus in freshwater sediments: a synthesis of recent works. Fresenius," Journal of Analytical Chemistry, vol. 78, no. 5, pp. 125-136, 2001.

[19] K. Pettersson, "Phosphorus characteristics of settling and suspended particles in Lake Erken," Science of the Total Environment, vol. 266, no. 1-3, pp. 79-86, 2001.

[20] C. L. Jin, Z. Q. Guo, D. C. Wang, and W. B. Zhu, "Brief introduction to water resources quality," Assessment of China, vol. 45, no. 5, pp. 58-66, 1996.

[21] L. Zhang, Study on Water Quality Model of Nanhu Lake, Wuhan University of Technology, 2006.

[22] B. Li, S. M. Ding, C. X. Fan et al., "Estimation of releasing fluxes of sediment nitrogen and phosphorus in Fubao Bay in Dianchi Lake," Environmental Science, vol. 32, no. 1, pp. 114-120, 2018.

[23] F. Y. Zheng, L. Tan, X. Chen, B. Li, T. T. Zhong, and Q. D. Cai, "Spatial distribution of nitrogen and phosphorus and pollution evaluation for sediment in Xiangxi Bay," Asian Journal of Ecotoxicology, vol. 13, no. 4, pp. 49-59, 2018.

[24] R. W. Li, "Sediment pollution and environmental sedimentology," Advances in Earth Science, vol. 13, no. 4, pp. 81-85, 1998.

[25] W. Yang and X. H. Yan, "Soil phosphorus cycle and its impact on soil phosphorus loss," Soil and Environment, vol. 34, no. 3, pp. 256-258, 2001.

[26] C. H. Meng and B. Zhao, "Vertical distribution of species of nitrogen and phosphorus in the sediments of Donghu Lake," Environmental Science, vol. 34, no. 7, pp. 1831-1837, 2008.

[27] B. Zhu, Z. Wang, and X. Zhang, "Phosphorus fractions and release potential of ditch sediments from different land uses in a small catchment of the upper Yangtze River," Journal of Soils and Sediments, vol. 12, no. 2, pp. 278-290, 2012.

[28] Q. X. He, S. Zhang, Z. X. Fang, and Y. Q. He, "Geochemical morphological distribution characteristics of nitrogen and phosphorus in sediments of Daya Bay," Tropical Ocean, vol. 8, no. 2, pp. 38-45, 1992.

[29] L. Zhao, X. Jiang, W. W. Wang, S. H. Wang, L. Chang, and J. Y. Chen, "Occurrence characteristics and bioavailability of different forms of nitrogen in surface sediments of Danjiangkou Reservoir," Journal of Yangtze River Resources and Environment, vol. 25, no. 4, pp. 630-637, 2016.

[30] S. L. Wen, Y. Q. Gong, T. Wu et al., "Characteristics and exchange flux of nitrogen and phosphorus in sediment-water interface of Yuqiao Reservoir," Environmental Science, vol. 39, no. 5, pp. 2154-2164, 2018.

[31] M. S. Bai, Y. Ban, P. Diplas, and F. Xiao, "Quantitative assessment of hydrological spatiotemporal changes in the middle and lower reaches of the Hanjiang River after Danjiangkou reservoir impoundment and its ecological impact," Journal of Yangtze River Resources and Environment, vol. 26, no. 9, pp. 1476-1487, 2017.

[32] R. N. Glud, J. K. Gundersen, N. P. Revsbech, and B. B. Jørgensen, "Effects on the benthic diffusive boundary layer imposed by microelectrodes," Limnology and Oceanography, vol. 39, no. 2, pp. 462-467, 1994. 
[33] Z. Q. Wang, B. Li, and R. J. Liang, "Comparative study on endogenous release of nitrogen and phosphorus in Nansi Lake, China," Journal of Environmental Science, vol. 33, no. 2, pp. 487-493, 2013.

[34] N. V. Vladimir, Statistical Learning Theory, Publishing House of Electronics Industry, Beijing, China, 2004.

[35] J. J. Liu, C. Y. Dong, Y. Q. Song, and P. D. Sun, “The seasonal variations of nitrogen and phosphorus release and its fluxes from the sediments of the Beili Lake in the Hangzhou West Lake," Chinese Journal of Ecology, vol. 32, no. 24, pp. 79327939, 2012.

[36] Z. Q. Wang, B. Li, X. H. Hu, and J. B. Liang, "Distribution characteristics of nitrogen, phosphorus, organic matter and their correlation analyses in the sediments of Nansi Lake China," Soil Science Bulletin, vol. 44, no. 4, pp. 867-874, 2013.

[37] P. Hohener and R. Gachter, "Nitrogen cycling across the sediment-water interface in an eutrophic, artificially oxygenated lake," Aquatic Sciences, vol. 56, no. 2, pp. 115-132, 1994.

[38] B. Li, Z. Q. Wang, Q. S. Wang, and J. B. Cuan, "Distribution characteristics and correlations of phosphorus in sediment and interstitial water of Nansi Lake, Shandong Province of East China in summer and winter," Chinese Journal of Applied Ecology, vol. 24, no. 6, pp. 1699-1706, 2013.

[39] C. Fan, L. Zhang, X. Bao et al., "Migration mechanism of biogenic elements and their quantification on the sediment-water Interface of Lake Taihu: I. spatial variation of the ammonium release rates and its source and sink fluxes," Journal of Lake Science, vol. 16, no. 1, pp. 11-21, 2004.

[40] B. Li, S. M. Ding, C. X. Fan et al., "Estimation of releasing fluxes of sediment nitrogen and phosphorus in Fubao Bay in Dianchi Lake," Environmental Science, vol. 31, no. 1, pp. 114-120, 2008.

[41] L. J. Hou, M. Liu, and S. Y. Xu, "Effects of environmental factors on endogenous phosphorus release from sediment in Suzhou City," Shanghai Environmental Science, vol. 290, no. 4, pp. 258-260, 2003.

[42] H. Xu, L. Zhang, J. Shang, and C. Fan, "Study on ammonium and phosphate fluxes at the sediment-water Interface of Lake Taihu using flow-through incubation," Journal of Ecology and Rural Environment, vol. 25, no. 4, pp. 66-71, 2009.

[43] L. Zhang, C. X. Fan, J. J. Wang, and C. H. Zheng, "Space-time dependent variances of Ammonia and phosphorus flux on sediment-water Interface in Lake Taihu," Environmental Science, vol. 11, no. 8, pp. 1537-1543, 2006.

[44] J. Wang, Y. Y. Yuan, H. M. Ye, X. F. Yang, and L. Tao, "Phosphorus forms and bioavailability in sediments of different rivers entering the lake in Hongze Lake," China Environmental Science, vol. 40, no. 10, pp. 4568-4579, 2020.

[45] X. Wang and F. Hao, "Zhang optimization of the best management measures for non-point source pollution in Danjiangkou Reservoir Basin," China Environmental Science, vol. 33, no. 7, pp. 1335-1343, 2013.

[46] T. Q. Yu, L. Wang, Y. Han, P. D. Ma, H. L. Wang, and J. M. Dong, "Fuzzy evaluation of water eutrophication in Xiaojiang River basin of three gorges reservoir area," Journal of AgroEnvironment Science, vol. 45, no. 4, pp. 1427-1431, 2008. 